\section{Zest Peach Series, Five Medium-chill Yellow-fleshed Cultivars}

\author{
David H. Byrne ${ }^{1}$ and Natalie Anderson \\ Department of Horticultural Sciences, Texas A\&M University, Horticulture- \\ Forestry Science Building, College Station, TX 77843-2133
}

Additional index words. fruit breeding, low chilling, nonmelting, Prunus persica

The Royal Zest peach series and the 'Golden Zest' peach are being released by Texas A\&M AgriLife to provide firm, attractive, yellow-fleshed, high-quality peaches for the medium chill zone. The Zest peach series consist of five cultivars that ripen consecutively to supply peaches over 5 weeks from approximately mid-May until late June in the medium-chill zone of Texas and similar regions.

\section{Origin}

In the late 1990s, the Prunus Breeding and Genetics Program began to develop a series of early ripening, yellow peach cultivars adapted to the medium chill zone (minimum chilling accumulation of 500 to 600 chilling units) of the southern United States. This work has resulted in five new peach cultivars that ripen consecutively from mid-May to late June in the medium chill zone of Texas. These cultivars have similar size but better color, fruit shape, and firmness when compared with commercial cultivars such as 'Regal', 'June Gold', and 'Harvester' (Tables 2 to 5; Figs. 1 and 2). 'Royal Zest One' (RZ1), 'Royal Zest Two' (RZ2), 'Royal Zest Three' (RZ3), and 'Royal Zest Four' (RZ4) resulted from crosses done between adapted breeding materials with a high-colored California cultivar. 'Golden Zest' (GZ) is a cross between a Californian and a Brazilian peach cultivar.

The Zest peaches [Prunus persica (Batsch) L.] originated in the Stone Fruit Breeding Program at the Department of Horticultural Sciences at Texas A\&M University located in College Station, TX, from crosses between selections adapted to the medium chill zone (TX2293-1, 'Victor', 'Agata') and two peaches from California ('Rich Lady' and 'Crimson Lady'). 'Royal Zest One' (RZ1, TX4B235) is a cross between a yellow-fleshed, medium-chill peach selection (TX2293-1 = 'Flordaking' open-pollinated) and the California cultivar Rich Lady, an early/midseason, yellowfleshed peach that was released by Zaiger Genetics. 'Rich Lady' is an open-pollinated seedling from ‘Amparo' (Zaiger et al., 1990).

Received for publication 20 Dec. 2013. Accepted for publication 4 Feb. 2014.

Research conducted at the Department of Horticultural Sciences, College Station, TX.

${ }^{1}$ To whom reprint requests should be addressed; e-mail dbyrne@tamu.edu.
'Royal Zest Two' (RZ2, TX4D165), 'Royal Zest Three' (RZ3, TX4E218), and 'Royal Zest Four' (RZ4, TX4E169) are sister seedlings, which originate from a cross between the yellow-fleshed California peach 'Rich Lady' and the early-ripening, medium-chill peach, 'Victor'. 'Victor' was released by Texas A\&M University for use in Spain and is a seedling from the cross between the low-chill, yellow-fleshed, midseason cultivar Tropic Beauty and the early-ripening, yellow-fleshed, medium-chill peach 'Goldprince'. 'Tropic Beauty' was jointly released by the University of Florida and Texas A\&M University (Rouse and Sherman, 1989) and is derived from a cross between a Florida selection Fla3-2 (K6E121 open-pollinated) and
Fig. 1. Fruit of the Royal Zest peach series.
'Flordaprince' (Fla2-7 × 'Maravilha'). 'Goldprince' was released by the USDA breeding program in Byron, GA (Okie, 1993) and is derived from a cross between 'Loring' and the Georgia selection FV3-257. 'Golden Zest' (GZ, TX4E220C) is a bright, golden yellow, clingstone peach with nonmelting flesh. It is from a cross between the California peach cultivar Crimson Lady and the Brazilian nonmelting cultivar Agata. 'Crimson Lady' is a high-chill, early-ripening, nonmelting, yellow-fleshed, clingstone peach released by Bradford in 1992, which resulted from a cross between the 'Red Diamond' nectarine and the 'Springcrest' peach (Bradford and Bradford, 1992; Okie et al., 1985). 'Agata' (Conserva 458), a nonmelting, processing peach, was released in 1985 by the EMBRAPA Fruit Breeding Program in Pelotas, Rio Grande do Sul, Brazil (Raseira et al., 1992). It is a selection from an openpollinated seed from the selection 682011041 acquired from Dr. Hough at Rutgers University in 1972 . This selection was derived from a cross between a nonmelting selection from New Jersey (NJC95) and a nonmelting, freestone from South Africa (SN45/3).

The original plants of these new releases were first identified in 2000-02. Two-yearold and older trees of the selection were subsequently evaluated during the 2004-11

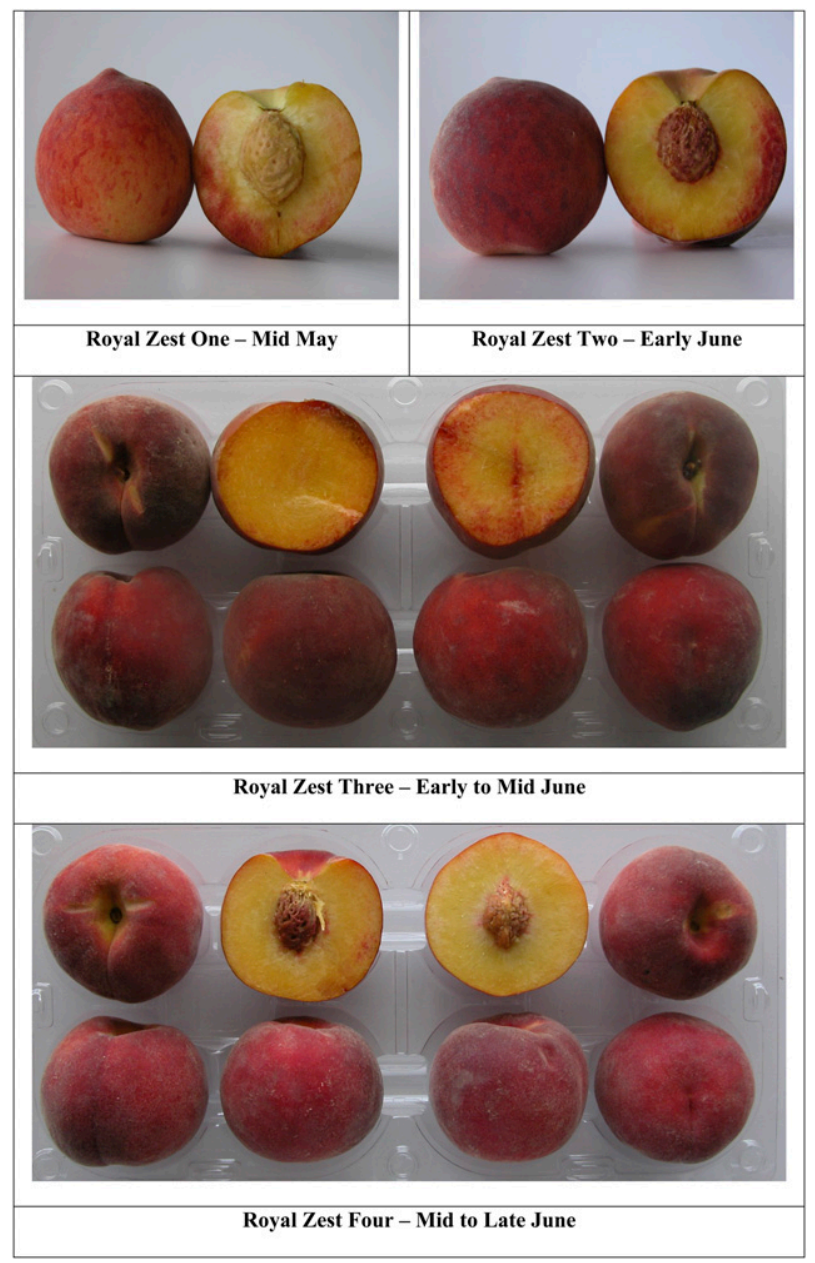


fruit growing seasons in four locations: three medium-chill sites (College Station, Fairfield, and Terrell, TX) and one higher chill location (Fowler, CA). College Station, TX (lat. $30^{\circ} 37^{\prime} \mathrm{N}$, long. $96^{\circ} 22^{\prime} \mathrm{W}, 94 \mathrm{~m}$ elevation), Fairfield, TX (lat. 31 $44^{\prime} \mathrm{N}$, long. $96^{\circ} 10^{\prime} \mathrm{W}, 134 \mathrm{~m}$ elevation), Terrell, TX (lat. $32^{\circ} 42^{\prime} \mathrm{N}$, long. $96^{\circ} 11^{\prime} \mathrm{W}, 151 \mathrm{~m}$

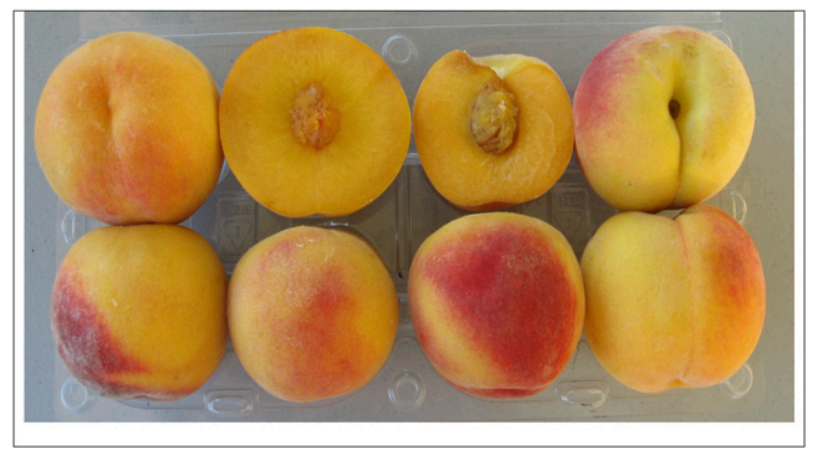

Fig. 2. Fruit of the Golden Zest peach. elevation), and the Fowler, CA, site (lat. $36^{\circ} 38^{\prime} \mathrm{N}$, long. $119^{\circ} 42^{\prime} \mathrm{W}, 92 \mathrm{~m}$ elevation) have a chilling accumulation that is generally above 550, 750, 700, and 800 chill units, respectively, as estimated with the mean monthly temperature of the coldest month (Byrne and Bacon, 1992; Sharpe, 1970; Weinberger, 1956) (Table 1).

\section{Description}

These five cultivars ripen consecutively from mid-May through late June (Tables 2 to 5). RZ1 and GZ are clingstone and the rest are semifreestones or freestones. All of the new releases have large fruit size and good to excellent flavor when properly managed and thinned. The mean soluble solids for these cultivars when picked mature are similar to or better than the common commercial cultivars. RZ1, RZ2, RZ3, and RZ4 have an attractive yellow ground color with a red blush over $60 \%$ to $95 \%$ of the fruit surface depending on the cultivar and environmental conditions. GZ has nonmelting flesh, an attractive golden yellow ground color with $20 \%$ to $30 \%$ red blush over the fruit surface (Tables 2 to 5; Figs. 1 and 2).

Although the Zest peaches bloom before 'June Gold' in the medium-chill zone (Table 2), they cropped consistently in the region where 'TexRoyal', JuneGold', and 'Harvester' are grown commercially. Based on the relative

Table 1. Chilling conditions at three Texas (College Station, Fairfield, and Terrell) and one California (Fowler) evaluation sites.

\begin{tabular}{|c|c|c|c|c|c|c|c|}
\hline \multirow[b]{2}{*}{ Location } & \multicolumn{2}{|c|}{ December temp $\left({ }^{\circ} \mathrm{C}\right)$} & \multicolumn{2}{|c|}{ January temp $\left({ }^{\circ} \mathrm{C}\right)$} & \multicolumn{2}{|c|}{ Chilling accumulation $^{z}$} & \multirow[b]{2}{*}{ Common commercial cultivars } \\
\hline & $\overline{\text { Mean }}$ & Range & $\overline{\text { Mean }}$ & Range & $\overline{\text { Mean }}$ & Range & \\
\hline Fairfield & 9.4 & $6.8-10.8$ & 8.9 & $6.7-12.9$ & 947 & $757-1303$ & June Gold, Harvester, Julyprince, GaLa \\
\hline
\end{tabular}

${ }^{2}$ Chilling estimated with the mean monthly temperatures of the two coldest months using the equation chilling $=4280-(68.8 *$ Dec/Jan mean monthly temperature in $\left.{ }^{\circ} \mathrm{F}\right)$ and chilling $=2079-\left(123.8^{*} \mathrm{Dec} / \mathrm{Jan}\right.$ mean monthly temperature in $\left.{ }^{\circ} \mathrm{C}\right)$. (Byrne and Bacon, 1992; Sharpe, 1970; Weinberger, 1956). Fairfield used data from Waco, Terrell used data from Dallas, and Fowler used data from the Fresno weather station. All Texas sites used data from 2000 to 2011 and the California site used data from 1975-96.

Table 2. Fruiting characteristics of the 'Zest' peaches compared with three medium-chill commercial peach cultivars at College Station, TX (2005-11).

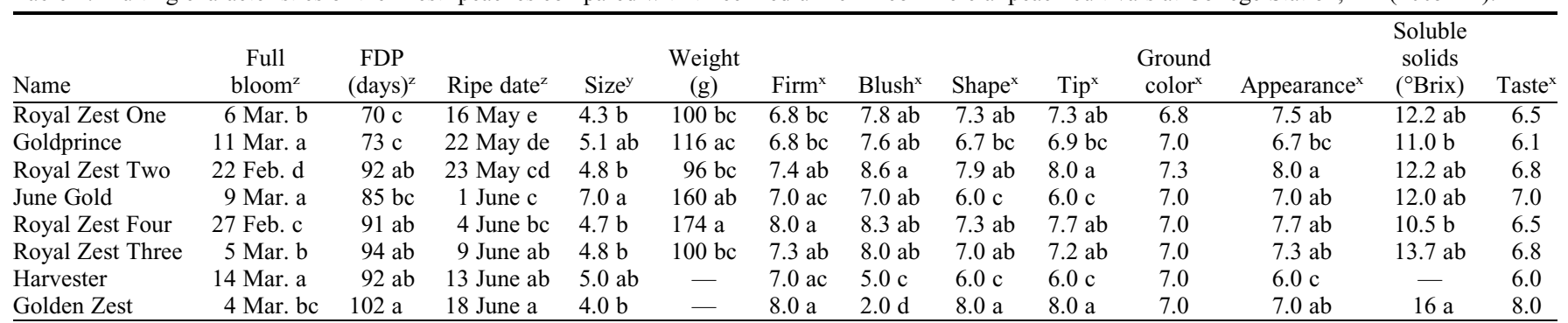

${ }^{2}$ Full bloom $=60 \%$ to $80 \%$ flowers open; FDP $=$ fruit development period, days from full bloom to ripe; Ripe date $=$ date when $20 \%$ of the fruit is firm ripe. ${ }^{y}$ Size ratings of diameter $(\mathrm{mm}) 0$ to $9 ; 4=51$ to $57,5=58$ to $64,6=65$ to $70,7=71$ to 76 .

${ }^{\times}$Rating scale 0 to $9 ; 0$ to 4 = unacceptable, $5=$ marginal, 6 = good, 7 = very good, 8 to $9=$ excellent for commercial use

Mean separation within columns by Duncan's multiple range test at the 5\% level. Items with the same letter are not significantly different. No letters within a column indicates no significant differences. SAS statistical program used for analysis of variance.

Table 3. Fruiting characteristics of the 'Zest' peaches compared with two medium-chill commercial peach cultivars at Fairfield, TX (2006-11).

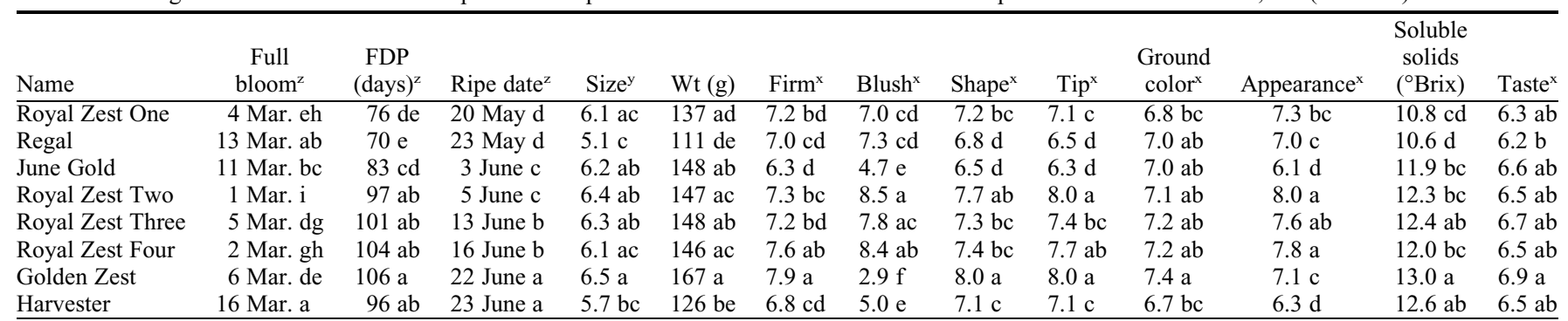

${ }^{\mathrm{x}}$ Full bloom $=60 \%$ to $80 \%$ flowers open; FDP $=$ fruit development period, days from full bloom to ripe; Ripe date $=$ date when $20 \%$ of the fruit is firm ripe.

${ }^{y}$ Size ratings of diameter (mm) 0 to $9,4=51$ to $57,5=58$ to $64,6=65$ to $70,7=71$ to 76 .

${ }^{\times}$Rating scale 0 to $9 ; 0$ to $4=$ unacceptable, $5=$ marginal, $6=\operatorname{good}, 7=$ very good, 8 to $9=$ excellent for commercial use.

Mean separation within columns by Duncan's multiple range test at the $5 \%$ level. Items with the same letter are not significantly different. No letters within a column indicates no significant differences. SAS statistical program used for analysis of variance. 


\begin{tabular}{|c|c|c|c|c|c|c|c|c|c|c|c|c|c|}
\hline Name & $\begin{array}{c}\text { Full } \\
\text { bloom }^{\mathrm{z}}\end{array}$ & $\begin{array}{c}\text { FDP } \\
{(\text { days })^{z}}^{2}\end{array}$ & Ripe date ${ }^{z}$ & $\operatorname{Size}^{y}$ & Wt (g) & $\operatorname{Firm}^{\mathrm{x}}$ & Blush $^{\mathrm{x}}$ & Shape ${ }^{x}$ & $\operatorname{Tip}^{x}$ & $\begin{array}{l}\text { Ground } \\
\text { color }^{x}\end{array}$ & Appearance $\mathrm{x}^{\mathrm{x}}$ & $\begin{array}{c}\text { Soluble } \\
\text { solids } \\
\left({ }^{\circ} \text { Brix }\right)\end{array}$ & Taste $^{\mathrm{x}}$ \\
\hline Royal Zest One & $23 \mathrm{Feb}$ & $92 \mathrm{~b}$ & 26 May f & $6.9 \mathrm{ab}$ & $164 \mathrm{~b}$ & $7.3 \mathrm{ab}$ & $6.7 \mathrm{bc}$ & $7.7 \mathrm{bc}$ & $7.7 \mathrm{ab}$ & $6.9 \mathrm{~b}$ & $7.2 \mathrm{ac}$ & 12.6 & 6.4 \\
\hline TexKing & $27 \mathrm{Feb}$ & $98 \mathrm{ab}$ & 6 June e & $7.1 \mathrm{ab}$ & $193 \mathrm{ab}$ & $6.8 \mathrm{ac}$ & $5.9 \mathrm{~cd}$ & $7.2 \mathrm{~cd}$ & $7.4 \mathrm{bc}$ & $6.7 \mathrm{~b}$ & $6.6 \mathrm{~cd}$ & 11.0 & 6.1 \\
\hline June Gold & - & - & 7 June de & $6.3 \mathrm{~b}$ & $178 \mathrm{ab}$ & $6.5 \mathrm{bc}$ & $4.8 \mathrm{de}$ & $7.0 \mathrm{~d}$ & $7.0 \mathrm{c}$ & $7.0 \mathrm{~b}$ & $6.0 \mathrm{de}$ & 12.5 & 6.5 \\
\hline Royal Zest Two & 23 Feb & $109 \mathrm{a}$ & 8 June de & $7.6 \mathrm{ab}$ & $193 \mathrm{ab}$ & $6.8 \mathrm{ac}$ & $8.7 \mathrm{a}$ & $8.1 \mathrm{ab}$ & $8.4 \mathrm{a}$ & $7.0 \mathrm{~b}$ & $8.1 \mathrm{a}$ & 12.2 & 6.4 \\
\hline Royal Zest Three & $25 \mathrm{Feb}$ & $109 \mathrm{a}$ & 14 June cd & $7.4 \mathrm{ab}$ & $179 \mathrm{ab}$ & $7.1 \mathrm{ab}$ & $6.9 \mathrm{bc}$ & $7.6 \mathrm{bc}$ & $7.8 \mathrm{ab}$ & $6.8 \mathrm{~b}$ & $7.2 \mathrm{bc}$ & 11.6 & 6.5 \\
\hline Sweet Delight Two & $25 \mathrm{Feb}$ & $108 \mathrm{a}$ & 17 June c & $8.1 \mathrm{a}$ & $236 \mathrm{a}$ & $7.4 \mathrm{ab}$ & $6.9 \mathrm{bc}$ & $7.8 \mathrm{bc}$ & $7.8 \mathrm{ab}$ & $6.9 \mathrm{~b}$ & $8.1 \mathrm{a}$ & 13.4 & 6.7 \\
\hline Royal Zest Four & $26 \mathrm{Feb}$ & $113 \mathrm{a}$ & 20 June ac & $6.9 \mathrm{ab}$ & $194 \mathrm{ab}$ & $7.5 \mathrm{a}$ & $8.4 \mathrm{ab}$ & $7.5 \mathrm{bc}$ & $7.9 \mathrm{ab}$ & $7.0 \mathrm{~b}$ & $8.0 \mathrm{ab}$ & 11.4 & 6.3 \\
\hline Harvester & - & - & 22 June $a b$ & $7.3 \mathrm{ab}$ & $180 \mathrm{ab}$ & $6.0 \mathrm{c}$ & $3.3 \mathrm{ef}$ & $7.7 \mathrm{bc}$ & $7.7 \mathrm{ab}$ & $6.7 \mathrm{~b}$ & $5.7 \mathrm{e}$ & 11.3 & 6.3 \\
\hline Golden Zest & $27 \mathrm{Feb}$ & - & 25 June a & $7.8 \mathrm{a}$ & $198 \mathrm{ab}$ & $7.6 \mathrm{a}$ & $2.8 \mathrm{f}$ & $8.4 \mathrm{a}$ & $8.4 \mathrm{a}$ & $7.8 \mathrm{a}$ & $7.4 \mathrm{ac}$ & 13.2 & 7.3 \\
\hline
\end{tabular}

${ }^{\mathrm{z}} \mathrm{Full}$ bloom $=60 \%$ to $80 \%$ flowers open; FDP $=$ fruit development period, days from full bloom to ripe; Ripe date $=$ date when $20 \%$ of the fruit is firm ripe.

${ }^{\mathrm{y}}$ Size ratings of diameter (mm) 0 to $9,4=51$ to $57,5=58$ to $64,6=65$ to $70,7=71$ to 76 .

${ }^{\mathrm{x}}$ Rating scale 0 to $9 ; 0$ to $4=$ unacceptable, $5=$ marginal, $6=$ good, $7=$ very good, 8 to $9=$ excellent for commercial use.

Mean separation within columns by Duncan's multiple range test at the $5 \%$ level. Items with the same letter are not significantly different. No letters within a column indicates no significant differences. SAS statistical program used for analysis of variance.

Table 5. Fruiting characteristics of the 'Zest' peaches compared with three medium-chill commercial peach cultivars at Terrell, Texas (2004-11).

\begin{tabular}{|c|c|c|c|c|c|c|c|c|c|c|c|}
\hline Name & Ripe date $^{z}$ & $\operatorname{Size}^{\mathrm{y}}$ & $\mathrm{Wt}(\mathrm{g})$ & Firm $^{x}$ & Blush $^{x}$ & Shape $^{x}$ & $\operatorname{Tip}^{x}$ & $\begin{array}{l}\text { Ground } \\
\text { color }^{\mathrm{x}}\end{array}$ & Appearance $^{\mathrm{x}}$ & $\begin{array}{l}\text { Soluble } \\
\text { solids } \\
\left({ }^{\circ} \text { Brix) }\right.\end{array}$ & Taste $^{x}$ \\
\hline Royal Zest One & 23 May e & $6.0 \mathrm{a}$ & 139 & 7.0 & $6.8 \mathrm{ab}$ & $7.4 \mathrm{ab}$ & $7.0 \mathrm{bc}$ & 6.4 & $7.0 \mathrm{bc}$ & $11.8 \mathrm{ab}$ & $6.4 \mathrm{ab}$ \\
\hline Regal & 26 May e & $5.0 \mathrm{~b}$ & 115 & 7.0 & $7.3 \mathrm{ab}$ & $7.0 \mathrm{~b}$ & $6.7 \mathrm{c}$ & 7.0 & $7.0 \mathrm{bc}$ & $10.0 \mathrm{~b}$ & $6.0 \mathrm{~b}$ \\
\hline Royal Zest Two & 13 June cd & $5.6 \mathrm{ab}$ & 114 & 7.4 & $8.5 \mathrm{a}$ & $7.5 \mathrm{ab}$ & $7.8 \mathrm{ab}$ & 7.1 & $7.8 \mathrm{ab}$ & $12.4 \mathrm{ab}$ & $6.4 \mathrm{ab}$ \\
\hline Royal Zest Three & 19 June bc & $5.9 \mathrm{a}$ & 120 & 7.4 & $7.8 \mathrm{ab}$ & $7.8 \mathrm{ab}$ & $7.6 \mathrm{ab}$ & 7.4 & $7.9 \mathrm{ab}$ & $12.8 \mathrm{ab}$ & $7.0 \mathrm{a}$ \\
\hline Royal Zest Four & 20 June $a b$ & $5.7 \mathrm{a}$ & 117 & 7.8 & $8.4 \mathrm{a}$ & $7.7 \mathrm{ab}$ & $7.6 \mathrm{ab}$ & 7.4 & $8.0 \mathrm{a}$ & $12.0 \mathrm{ab}$ & $6.6 \mathrm{ab}$ \\
\hline Golden Zest & 29 June $a b$ & $5.6 \mathrm{ab}$ & 118 & 8.0 & $1.9 \mathrm{~d}$ & $8.0 \mathrm{a}$ & $8.1 \mathrm{a}$ & 7.3 & $7.3 \mathrm{ac}$ & $14.4 \mathrm{a}$ & $6.7 \mathrm{ab}$ \\
\hline Harvester & 4 July a & $5.3 \mathrm{~b}$ & 120 & 7.0 & $5.0 \mathrm{c}$ & $7.0 \mathrm{~b}$ & $7.0 \mathrm{bc}$ & 7.3 & $6.3 \mathrm{c}$ & $13.0 \mathrm{a}$ & $6.7 \mathrm{ab}$ \\
\hline
\end{tabular}

${ }^{\mathrm{z}}$ Ripe date $=$ date when $20 \%$ of the fruit is firm ripe.

${ }^{\text {y }}$ Size ratings of diameter $(\mathrm{mm}) 0$ to $9 ; 4=51$ to $57,5=58$ to $64,6=65$ to $70,7=71$ to 76 .

${ }^{x}$ Rating scale 0 to $9 ; 0$ to $4=$ unacceptable, $5=$ marginal, $6=$ good, $7=$ very good, 8 to $9=$ excellent for commercial use.

Mean separation within columns by Duncan's multiple range test at the $5 \%$ level. Items with the same letter are not significantly different. No letters within a column indicates no significant differences. SAS statistical program used for analysis of variance.

bloom times of standard cultivars, these new peaches need between 500 and 600 chilling units (CU). The latest blooming releases $\mathrm{RZ1}$, RZ4, and GZ require $600 \mathrm{CU}$, whereas $\mathrm{RZ3}$ requires $550 \mathrm{CU}$ and $\mathrm{RZ2}$ requires $\approx 500$ CU to break dormancy.

The stones are elliptical to ovate in shape. RZ1, RZ3, RZ4, and GZ have larger stones (length 31 to $36 \mathrm{~mm}$, width 21 to $26 \mathrm{~mm}$, thickness 16 to $19 \mathrm{~mm}$ ) than does RZ2 (length 28 to $30 \mathrm{~mm}$, width 18 to $23 \mathrm{~mm}$, thickness 16 to $17 \mathrm{~mm}$ ).

Flowers of RZ1 are non-showy, whereas RZ2, RZ3, RZ4, and GZ have showy flowers. All the new peach cultivars have five pink petals with the non-showy petals being a darker pink and smaller than the showy petals. Pollen is yellow and abundant. The trees are self-fertile.

The trees are vigorous with the typical semispreading growth habit similar to 'TexPrince', and 'TexRoyal'. No observations have been made on resistance for either peach rust or bacterial leaf spot. The leaves are lanceolate with acuminate apices and crenate margins. RZ1, RZ3, and GZ have small globular petiolar glands, whereas RZ2 and RZ4 have reniform petiolar glands.

\section{Availability}

Requests for budwood should be directed to The Texas A\&M University System's Office of Technology Commercialization. These cultivars are the subject of plant patent applications.

\section{Literature Cited}

Bradford, L.G. and N.G. Bradford. 1992. Peach tree (Crimson Lady). United States Patent \# 7,953. 25 Aug. 1992.

Byrne, D.H., and T.A. Bacon. 1992. Chilling estimation: Its importance and estimation. The Texas Horticulturist 18:5-8-9.
Okie, W.R. 1993. 'Goldprince' and 'Scarletpearl' peaches. HortScience 28:231.

Okie, W.R., D.W. Ramming, and R. Scorza. 1985. Peach, nectarine, and other stone fruit breeding by the USDA in the last two decades. HortScience 20:633-641.

Raseira, M.C.B., B.H. Nakasu, A.M. Santos, J.F. Fortes, O.M. Martins, A. Raseira, and J. Bernardi. 1992. The CNPFT/EMBRAPA fruit breeding program in Brazil. HortScience 27:11541157.

Rouse, R. and W. Sherman. 1989. 'TropicBeauty': A low-chilling peach for subtropical climates. HortScience 24:165-166.

Sharpe, R.H. 1970. Subtropical peaches and nectarines. Fla. State Hort. Soc. 82:302306.

Weinberger, J.H. 1956. Prolonged dormancy trouble in peaches in the southeast in relation to winter temperatures. Proc. Amer. Soc. Hort. Sci. 67:107-112.

Zaiger, C.F., G.N. Zaiger, L.M. Gardner, and G.G. Zaiger. 1990. Peach tree 'Rich Lady'. United State Patent \# 7, 290. 7 Aug. 1990. 